\title{
Labour Market, Work Mentality and Syndicalism: Dock Labour in the United States and Hamburg, 1900-1950s
}

\author{
KLAUS WEINHAUER
}

SUmmary: This international comparison firstly examines labour market organization, casual labour and work mentality in North American seaports and in Hamburg. By contrast to British ports, these ports finally dispensed with casual labour between the world economic crisis and the Second World War, and labour markets there were centralized. Secondly, the industrial militancy of mobile dockworkers without permanent jobs is examined through a consideration of syndicalist organizations (1919-1921), and interpreted as an interplay of experiences with power in the network of labour market, workplace and docklands. The study refers repeatedly to the decisive dividing line between regularly and irregularly employed dockworkers. National differences in trade union representation and dispute behaviour are analysed by reference to dockworkers' direct actions.

\section{STATEMENT OF THE PROBLEM AND CURRENT STATE OF RESEARCH}

There is already a wide range of comparative studies in labour history. Such comparisons can provide a new stimulus for the much-discussed question of the future of labour history. In the process, not only should recent methodological approaches (such as analysis of language or of the relationship between the sexes) be put to the test, but "mistaken or premature certainties" should also be re-examined.' The areas predominantly treated in the most recent comparative international case studies are mining and the engineering industry. Strike research too appears to concentrate on the analysis of these occupational groups. ${ }^{2}$ By comparison

'On the theoretical basis for comparative studies, see Thomas Welskopp, "Stolpersteine auf dem Königsweg. Methodenkritische Anmerkungen zum intemationalen Vergleich in der Gesellschaftgeschichte", Archiv fiir Sozialgeschichte, 35 (1995), pp. 339-367 (quote on p. 361), and the articles by Christiane Eisenberg and Marcel van der Linden/Jurgen Rojahn in ibid., 34 (1994) and 35 (1995).

2 For case studies, see Thomas Welskopp, Arbeit und Macht im Hättenwerk. Arbeits- und industrielle Beziehungen in der deutschen und amerikanischen Eisen- und Stahlindustrie von den 1860er bis zu den 1930er Jahren (Bonn, 1994); Klaus Tenfelde (ed.), Towards a Social History of Mining (Munich, 1991); Jeffrey Haydu, Benveen Craft and Class. Skilled Workers and Factory Politics in the United States and Britain, 1890-1922 (Berkeley, Los 
another economically important group, the dockworkers, lead only a shadowy existence. It is not only the key position held by dockworkers in international goods traffic that suggests the importance of an international comparison; their apparently highly developed tendency to strike also cries out for a comparative analysis. After all, this example can be used to demonstrate what advances in understanding have been made by recent socio-historical research since the mid-1950s, when in an international survey of the industry Clark Kerr and Abraham Siegel referred to dockworkers and others as being most prone to strike. ${ }^{3}$

As the following comparative analysis will show, it is high time that some old certainties of dock labour research are reviewed critically. One aspect to be questioned is the assumption that there was an industry-wide strike behaviour which remained unchanged over the years. In view of the many questions which remain open, the present study has had to be restricted in two ways. First, it concentrates on a comparison between North American ports and Hamburg, by far the largest German port, which also played an important role for the whole of Europe. ${ }^{4}$ Second, the concept of dockworker is largely restricted to those groups involved directly in the transfer of goods on the ships. In Hamburg these were the Schanerleute or dockers, in the American ports the longshoremen in particular. The selection of ports in North America (particularly San Francisco and New York) suggests itself because there, as in Hamburg, there were strong radically left-wing Unionen or syndicalist organizations and movements. This is a good starting-point for a comparative examination of the driving forces and structural conditions underlying dockworkers' behaviour in

Angeles and London, 1988); Leopold Haimson and Giulio Sapelli (eds), Strikes, Social Conflict and the First World War (Milan, 1992); Leopold Haimson and Charles Tilly (eds), Strikes, Wars, and Revolutions in an International Perspective. Strike Waves in the Late Nineteenth and Early Twentieth Centuries (Cambridge [etc.], 1989). For a wider coverage of different trades, see Friedhelm Boll, Arbeitskämpfe und Gewerkschaften in Deutschland, England und Frankreich. Ihre Entwicklung vom 19. zum 20. Jahrhundert (Bonn, 1992).

${ }^{3}$ Older comparative studies are: Horst Jürgen Helle, Die unstetig beschaffigten Hafenarbeiter in den nordwesteuropaischen Häfen. Eine industriesoziologische Untersuchung in Antwerpen, Bremen, Bremerhaven, Hamburg und Rotterdam (Stuttgart, 1960); Vernon H. Jensen, Hiring of Dockworkers and Employment Practices in the Ports of New York. Liverpool, London, Rotterdam and Marseilles (Cambridge, 1964); for more recent historical studies, see Michael Grdttner, "The Rank-and-File Movements and the Trade Unions in the Hamburg Docks from 1896-7", in Wolfgang J. Mommsen and Hans-Gerhard Husung (eds), The Development of Trade Unionism in Great Britain and Germany, 1880-1914 (London, Boston and Sydney, 1985), pp. 114-129; Svend Aage Andersen, Dockers' Clllture in Three North European Port Cities: Hamburg. Gothenburg and Aarhus, 1880-1960 (Aarhus, 1990).

- For the present state of research on the labour history of these countries, see in addition to the works listed in footnote 2 the special number of the Imternational Labor and Working-Class History, 46 (1994): "What Next for Labor and Working-Class History?", and the supplementary volume of the International Review of Social History, 38 (1993): "The End of Labour History?". 
conflict situations and their organizational behaviour generally. ${ }^{5}$ The study also links the analysis of long-term developmental processes (e.g. in the organization of the labour market) with the reconstruction of dockworkers' norms and value schemes. This has been done because recent studies in labour history have shown how deadlocked lines of discussion can be revitalized by an examination of attitudes to work. ${ }^{6}$ This method can also help to cast light on the grey area between individual and collective behaviour. Many socio-historically important differentiations in dock work also have to be discussed, and for this reason too the restriction to two countries is necessary, since an article is limited in the amount it can cover.

The ports in the two countries differed sharply from each other in their political situations. Hamburg was a stronghold of the reformist socialdemocratic labour movement. During the Weimar Republic the Social Democratic Party (SPD) always formed a part of the city-state's government. Among dockworkers, too, the social-democratic German Transport Workers Association (DTV) was dominant. This trade union, which also included other occupations such as carters, coach drivers and postal workers, covered about two-thirds of Hamburg's dockworkers between 1928 and $1932 .{ }^{7}$ As is generally known, there was no social-democratic or socialist party with anything approaching that level of influence in the United States generally or in the two ports examined here. However, between 1934 and 1938 short-lived movements for socialist-oriented independent or Farmer-Labour parties did come into being. ${ }^{8}$ Just as the revolution of November 1918 stimulated the activities of the Hamburg

${ }^{3}$ Due to the unsatisfactory current state of socio-historical research it is not possible to distinguish here between radically left-wing Unionen and syndicalist directions or between organizations and movements. For stylistic reasons, only the term "syndicalist organizations" is used in what follows. For a survey, see Marcel van der Linden and Wayne Thorpe (eds), Revolutionary Syndicalism: An International Perspective (Aldershot, 1990); Hans Manfred Bock, Syndikalismus und Linkskommunismus von 1918-1923. Ein Beitrag zur Sozial- und Ideengeschichte der frühen Weimarer Republik, new updated edition with epilogue (Darmstadt, 1993; 1st. ed. Meisenheim, 1969).

- See Michael Seidman, Workers against Work. Labor in Paris and Barcelona during the Popular Fronts (Berkeley, 1991); and idem, "Individualisms in Madrid during the Spanish Civil War", Journal of Modern History, 68 (1996), pp. 63-83; Gordon Phillips and Noel Whiteside, Casual Labour. The Unemployment Question in the Port Transport Industry 1880-1970 (Oxford, 1985).

'See Klaus Weinhauer, Alltag und Arbeitskampf im Hamburger Hafen. Sozialgeschichte der Hamburger Hafenarbeiler 1914-1933 (Paderborn [etc.], 1994), esp. pp. 248 and 309. The DTV was renamed as the German Transport Association (Deutscher Verkehrsbund). After its amalgamation with the Association of Local Authority and Government Workers (Verband der Gemeinde- und Staatsarbeiter), its name was again changed in 1930 to Joint Association of Employees in Public Enterprises, Passenger and Goods Transport (Gesamtverband der Arbeitnehmer der öffentlichen Betriebe und des Personen- und Warenverkehrs).

- See Bruce Nelson, Workers on the Waterfront: Seamen, Longshoremen, and Unions in the 1930s (Urbana and Chicago, 1988), p. 185f. In San Francisco, the United Labor Party candidate was unsuccessful in the mayoral election of 1935. 
dockworkers, the pro-labour regulations of the New Deal phase ${ }^{9}$ played a similar role for the organizational and conflict behaviour of their counterparts in US ports.

In an international comparison, Frank Broeze has recently contrasted the militancy of sailors and dockworkers with the often pragmatic line adopted by their union leaders. ${ }^{10}$ While his study presents an impressive survey of the international literature up to the late 1980s, it remains less than fully convincing due to the socio-historical shortcomings of the works analysed. Thus only a general outline of the reasons for maritime workers' militant attitude could be given. This, it is claimed, was to be attributed to their homogeneous living and working conditions, separate from the rest of society, and this was linked to low social mobility and both geographical and cultural isolation. ${ }^{11}$ It is also left unclear if and when Broeze is referring to dockworkers' industrial militancy or to their political radicalism.

In his research on the seamen and dockworkers of the west coast of North America, Bruce Nelson makes the important suggestion that the waterfront with its "close affinity between work and life, and the absence of integrative institutions" makes syndicalism "[.. .] less as doctrine than as a mood and tendency" a "natural component of the maritime workers' world view". ${ }^{12}$ This thesis, while important in itself, at the same time demonstrates how essential a comparative international approach to the research is. Nelson has failed to notice that John Lovell reached a very similar conclusion for London dockworkers in 1969, and Michael Grüttner substantiated it for Hamburg dockworkers in the mid-1980s. Additionally, Nelson bases his statements only on the analysis of the living conditions of seamen on board merchant ships and a glance at the subculture of the harbour milieu. In the study, with its strong emphasis on organization, no

9n previous research, see David Montgomery, "Labor and the Political Leadership of New Deal America". International Review of Social History, 39 (1994), pp. 335-360; Robert Zieger, "History of the CIO. A Symposium", Labor History, 37 (1996), pp. 157188.

${ }^{10}$ Frank Broeze, "Militancy and Pragmatism. An International Perspective on Maritime Labour, 1870-1914", International Review of Social History, 36 (1991), pp. 165-200: Dieter Nelles is working on an extremely promising project on the resistance by German seamen; see e.g. Dieter Nelles, "Ungleiche Partner. Die Zusammenarbeit der Internationalen Transportarbeiter-Föderation (ITF) mit den Westalliierten Nachrichtendiensten", Internationale wissenschaftliche Korrespondenz zur Geschichte der deutschen Arbeiterbewegung, 30 (1994), pp. 534-562.

"See Broeze, "Militancy and Pragmatism", p. 174.

12 See Nelson, Workers on the Waterfront, p. 183 (quote on p. 8). See also, by the same author, "Pentecost' on the Pacific: Maritime Workers and Working-Class Consciousness in the 1930s". Political Power and Social Theory, 4 (1984), pp. 141-182; and "Unions and the Popular Front: The West Coast Waterfont in the 1930s", International Labor and Working-Class History, 30 (1986), pp. 59-78. See John Lovell, Stevedores and Dockers. A Study of Trade Unionism in the Port of London 1870-1914 (London, 1969), p. 156; Gruttner, "Rank-and-File", p. 119. 
answer is given to the question of how these behavioural pattems arose in the interaction of working conditions, labour-market conditions, work mentality and housing environment; for the "oppressive conditions of work" and the labour-market situation are described only in isolation from each other, and in very general terms. ${ }^{13}$

Eric Amesen's study of white and non-white dockworkers in New Orleans attributes only a marginal role to the Industrial Workers of the World (IWW). ${ }^{14}$ While Amesen takes a positive attitude to Nelson's view that dockworkers had a general syndicalist tendency, he disputes that this was closely linked to political radicalism. Instead he emphasizes that the trade union umbrelia organization founded in 1901, the Dock and Cotton Council (DCC), did not operate as a syndicalist One Big Union in New Orleans. It was dominated by the highly specialized trades with a strong position on the labour market, in particular the cotton screwmen and the longshoremen. Amesen emphasizes the importance of the union-controlled labour market for the successes of the cotton screwmen and longshoremen, but qualifies this by stating that while the DCC did unite harbour occupations across trade boundaries and ethnic divisions, it frequently neglected the interests of workers on the lower rungs of the occupational status ladder. Thus the successes of the cotton screwmen and longshoremen were based in part on the exclusion of other trades. ${ }^{15}$ Howard Kimeldorf has pursued the reasons for the origin of radical or conservative trade unions in the US West Coast ports and in New York in greater depth. ${ }^{16}$ For instance, he qualifies the importance of an isolated way of life, emphasizing that at

13 See also the critical remarks of Rick Halpern, "Organized Labour, Black Workers and the Twentieth-Century South: the Emerging Revision", Social History, 19 (1994), pp. 359383.

${ }^{14}$ See Eric Arnesen, Waterfront Workers of New Orleans. Race, Class, and Politics, 18631923 (New York and Oxford, 1991), p. 175; and on what follows, see ibid., pp. 176, 179 and 207. This problem is unfortunately passed over by Daniel Rosenberg, New Orleans Dockworkers: Race, Labor, and Unionism, 1892-1923 (New York, 1988). See the summary in Halpem, "Organized Labour", p. $368 f$.

is For further details, see Amesen. Waterfront Workers of New Orleans and also idem, "To Rule or Ruin. New Orleans Dockworkers' Struggle for Control 1902-1903", Labor History, 28 (1987), pp. 139-166; as a regional comparison, see also his contribution " 'It Ain't Like They Do in New Orleans': Race Relations, Labor Markets, and the Waterfront Labor Movements in the American South, 1880-1923", in Marcel van der Linden and Jan Lucassen (eds), Racism and the Labour Market: Historical Studies (Bem [etc.], 1995), pp. $57-100$.

${ }^{16}$ See the following contributions by Howard Kimeldorf: Reds or Rackets? The Making of Radical and Conservative Unions on the Waterfront (Berkeley [etc.], 1988); "The Social Origins of Radical and Conservative Union Leadership", in Maurice Zeitlin (ed.), How Mighty A Force (Los Angeles, 1983), pp. 307-369; "Sources of Working-Class Insurgency: Politics and Longshore Unionism during the 1930s", in Maurice Zeitlin (ed.), Insurgent Workers (Los Angeles, 1987), pp. 7-70; "Working-Class Culture, Occupational Recruitment, and Union Politics", Social Forces, 64 (1985), pp. 359-376; "World War II and the Deradicalization of American Labor. The ILWU as a Deviant Case", Labor History, 33 (1992), pp. 248-278. 
most this provides the necessary framework for certain behavioural patterns. However, the political direction these take is shaped by the way in which people organize their lives in the workplace and in their housing districts. Kimeldorf demonstrates the central role played by the extreme occupational mobility of the dockworkers, seamen and lumberjacks in making it possible for strong syndicalist trends and organizations to develop in, for instance, the West Coast ports in contrast to New York. ${ }^{17}$

Socio-historical studies of Hamburg dockworkers have produced even more differentiated results. Their broad-based analysis of labour and labour-market conditions point to an important internal differentiation within this occupational group. Thus the division into skilled and unskilled labourers or qualified and unqualified workers has not proved very productive analytically, as all the Hamburg dock trades apart from the lightermen consisted of unskilled labour. ${ }^{18}$ Instead, these studies were able to distinguish two different types of workers, relative both to their living and working situation and to their conflict and organization behaviour: these were on the one hand the dockworkers who had a regular contract of employment with a specific company, and on the other those who were in irregular employment, with the casual worker as the extreme case. The regularly employed dockworkers were oriented more towards the long term in their living and organizational situations, and in their case open confrontations with employers were the last resort in resolving disputes. Their colleagues in irregular employment favoured short-term goals and solutions and pursued their labour disputes in direct confrontation with the employers. However, this does not mean that the regularly employed never went on strike, only that they did so less often than their irregular counterparts. In this differentiation, the factors analysed were the already mentioned occupational mobility and ties to a particular company, but also the following: the role of team work and the size of the work teams, working hierarchies and command hierarchies in the workplace, the influence of mechanization on the work processes, and whether and to what extent the working procedures of individual dock trades were dependent on or influenced by other trades. The question of the scope for individual or collective activity was also examined, as were possibilities of communication in the workplace, in the labour market and in the harbour districts of the cities. ${ }^{19}$ So far, only Gordon Phillips and Noel Whiteside have exam-

17 See Kimeldorf, "Working Class Culture", p. 363f.

${ }^{18}$ See the pioneering study by Michael Gruttner, Arbeitswelt an der Wasserkante. Sozialgeschichte der Hamburger Hafenarbeiter 1886-1914 (Göttingen, 1984); and idem, "Das Konfliktpotential der Hafenarbeiter", in A. Herzig and G. Trautmann (eds). "Der kilhnen Bahn nur folgen wir ...", vol. 2, Arbeiter und technischer Wandel in der Hafenstadt Hamburg (Hamburg, 1989), pp. 153-175: also Weinhauer, Alltag, and idem, "Zwischen Betrieb und Straße: Arbeit, Konflikt und Organisation der Hamburger Hafenarbeiter 1918-1933". Internationale wissenschaftliche Korrespondenz zur Geschichte der deutschen Arbeiterbewegung, 31 (1995), pp. 6-24.

19 See Weinhauer, "Zwischen Betrieb", p. $23 f$. 
ined the "culture of work" of casual labourers for British ports. ${ }^{20}$ Here it is already difficult to resist the impression that this casual labour in particular made dock work particularly susceptible to disputes, as in the case of the Hamburg dockworkers.

Two general impressions emerge from this survey of the literature. First, the studies on North American ports and on Hamburg differ from each other in their method, but also in their research emphasis. Whereas broadbased socio-historically-oriented studies exist for Hamburg, the majority of studies of the US ports concentrate more on the trade unions, their leading personalities and on strikes; working and living conditions such as housing are not examined in any detail, nor is the interaction between these and the origin of trade unions and strikes. For this reason, this interaction must be demonstrated in the present article, with particular reference to Hamburg. Second, however, this survey has shown that despite all the differences in the international research, two problem areas feature repeatedly: one is the organization of the labour market and the closely related question of casual labour, and the other is the syndicalist tendencies of the dock labour force. The present study will concentrate primarily on these two problems. It will also pursue the difference between regular and irregular employment developed in relation to Hamburg, and the related framework of questions for comparative study listed above.

After a brief sketch of working conditions, casual work and the organization of the labour market will be analysed. This is not only a matter of power relationships in the labour market but also of the effect of each kind of job allocation on the work mentality of the workers concerned. After a glance at the characteristics of the harbour districts of the cities, the study will then focus on a landmark feature of the ports in the years after the First World War - the strong syndicalist organizations. The analysis of the interplay between working conditions, labour-market relationships, work mentality and the milieu of the dock areas is intended to examine how mass support for these organizations arose. Thus my approach will concentrate on only one important aspect of the broad spectrum of dockworkers' industrial militancy; the basic structural conditions underlying this militancy will not be examined. Next, the form of dispute often associated with these movements, direct action, will be considered critically. International comparisons will be employed in order to clarify whether this apparently uniform pattern of dispute was actually to be found among the dockworkers of all the ports considered here. Nevertheless, all these points should not be taken to suggest that industrial militancy can simply be equated with political radicalism, for, as both Howard Kimeldorf and my own research have shown, dockworkers were not predisposed to be sympathetic towards radical political parties, in this case the Communist Party (KPD). This was all the more true when the party

See also Phillips and Whiteside, Casual Labour. 
put forward political demands which had little to do. with the working and living conditions of the dockworkers. ${ }^{21}$ The relationship between behaviour at industrial level and activity in political affairs (such as elections and party membership) therefore still remains to be clarified.

\section{WORKING CONDITIONS, CASUAL LABOUR AND THE LABOUR MARKET}

In 1930, around 16,000 workers were employed in the Port Industry Association (Hafenbetriebsverein, HBV) in Hamburg. Only rough estimates exist for New York; these assume a total of some 50,000 dockworkers in the mid-1920s. About 10,000 to 15,000 worked in New Orleans at the start of the twentieth century, and in San Francisco there were in total about 8,000 dockworkers in $1933 .^{22}$ In Hamburg in 193660 per cent of the largest port trade, the dockers, were former seamen. Many seamen and lumberjacks worked in the US West Coast ports, too, in contrast to New York. A number of different trades came under the umbrella of dock work. Depending on the cargoes to be handled, there were special workers for grain, coal and warehouse goods, as well as the jobs of the lightermen and crane drivers. Except during the war years, dock work was men's work and team work. The number of workers employed in such a team, known as a gang, depended on the cargo and varied between four and thirty. ${ }^{23}$ There were no occupational hierarchies in these gangs, but because of the increased working speed and lifting power of the ships' winches it became necessary to employ specialists to work with the winches in Hamburg and on the US West Coast. This differentiation had established itself from about the $1920 \mathrm{~s} .{ }^{24}$ In general, it may be said that the gangs of dockers and

${ }^{21}$ See Kimeldorf, Reds or Rackets?, p. 83f.; Weinhauer, Alliag, pp. 334 and 392 . The switch of industrial militancy into political radicalism is discussed comprehensively by Dick Geary in Arbeiterprotest und Arbeiterbewegung in Europa 1848-1939 (Munich, 1982), pp. 45-71, and in idem, "Identifying Militancy: The Assessment of Working-Class Attitudes Towards State and Society", in Richard J. Evans (ed.), The German Working Class (London, 1982), pp. 220-242.

22 See Weinhauer, Alltag, p. 47; Carl von During, Der Gesamthafenbetrieb des Hafens Hamburg (Hamburg, 1936), p. 43; on the high proportion of seamen involved, see Wilhelm Prusse, Der Seemannsberuf und die Problematik seines Arbeitseinsatzes und der Nach. wuchslenkung (Rostock, 1940), p. 121; and on the US details, see Kimeldorf, "WorkingClass Culture", p. 361; "Longshore Labor Conditions in the United States", Monthly Labor Review, 31 (1930), pp. 811-830 and 1055-1069, esp. p. 817; Amesen, Waterfont Workers of New Orleans, p. viii; Stanley Weir, "Informal Workers' Control. The West Coast Longshoremen" (unpublished manuscript), p. 60.

${ }^{23}$ For details, "Productivity of Labor in Loading and Discharging Ship Cargoes", Monthly Labor Review, 32 (1931), pp. 255-284, esp. 268, 273 and 278; Lincoln Fairley, Facing Mechanization. The West Coast Longshore Plan (Los Angeles, 1979), p. 13; Lester Rubin, The Negro in the Longshore Industry (Philadelphia, 1974), p. 10f.; Weinhauer, Alltag, p. 55; Rosenberg, New Orleans Dockworkers, p. 53; Amesen, "To Rule or Ruin", p. 146.

24 See Weinhauer, Alltag, p. 55; Fairley, Facing Mechanization, p. 13. 
longshoremen, in particular, worked in a relatively self-determined way. They were not dependent on any direct preparatory work, nor on the working speed of workers from other trades. Nevertheless, as could be shown in the case of Hamburg, ${ }^{25}$ the foremen had considerable power over the gangs working in the ships' holds; all the more so if the workers had been taken on directly by the foreman and so were dependent on his goodwill.

Even before the First World War, the loading and unloading of bulk cargo like coal and grain had been mechanized in Hamburg and in the British ports. However, on the US West Coast, grain was still transferred in sacks up to the Second World War. The handling of general cargo did not undergo any major transformation until the $1950 \mathrm{~s}^{26}$ Simple tools such as the stevedore's hook and the sack barrow still predominated in this area into the inter-war years, although many US dock companies attempted to increase the level of mechanization during the First World War and in the 1920s. In this period the electric truck became a universal mechanical aid in Hamburg. The introduction of the pallet, brought into US ports in the $1940 \mathrm{~s}$, and the fork-lift truck, which became common in the 1950s, marked the first stages of change, but these were minor in comparison with the effects of containerization, which accelerated enormously during the $1960 \mathrm{ss}^{27}$ This slow rate of technological change - not to be equated with an unchanged work rate - explains why the working methods of the dockers and longshoremen underwent little change over a relatively long period.

Dock work in all countries was particularly characterized by the irregular and unpredictable arrival of the ships. In addition there were seasonal variations, caused by the harvesting of agricultural products (such as grain and cotton) for instance. As a result of this differential levels of work, a large number of workers constantly had to be allocated to the various jobs available. Within such a framework the distribution of power relationships in the labour market takes on central importance, for "[...] whoever controlled the hiring process quite literally ran the waterfront - deciding who would work, for how long, and under what conditions". ${ }^{28}$ Until the begin-

2s See Klaus Weinhauer, "Unfallentwicklung und Arbeitsprozeß im Hamburger Hafen 1896/97-1936", in Karl Lauschke and Thomas Welskopp (eds), Mikropolitik in Unternehmen. Arbeitsbeziehungen und Machtstrukturen in industriellen Großbetrieben des 20. Jahrhunderts (Essen, 1994), pp. 107-122, esp. 120 f.

${ }^{26}$ See Gruttner, Arbeitswelt, pp. 42-48; Amesen, Waterfront Workers of New Orleans, p. 226f.; Rubin, Negro in the Longshore Industry; p. 27f.; Phillips and Whiteside, Casual Labour, p. 32; and from a contemporary viewpoint, see "Studienreise nach den nordamerikanischen Hafen 1929" (Hamburg, 1930) (manuscript).

27 See Fairley, Facing Mechanization, pp. 54-58; and the graphic interview extracts in William Di Fazio, Longshoremen. Community and Resistance on the Brooklyn Waterfont (South Hadley, 1985), ch. 3.

2s Kimeldorf, Reds or Rackets?! p. 29; see also Amesen, Waterfront Workers of New Orleans, p. 43, and for a Canadian port Jessic Chisholm, "The St. John's Longshoremen's 
ning of the twentieth century, dock work both in Hamburg and in the United States had been characterized by casual labour. That is, the port companies often only employed workers short-time when ships had to be loaded or unloaded, and laid them off immediately the ships had left the port. However, it was only possible to make intensive use of casual labour if there were enough workers available who were prepared to live with such short-term and unpredictable employment conditions; that is, in all the countries under consideration the dockworkers were merely one part of the large casual labour market. Many casual labourers were also employed on sea-going ships, in the shipyards, on building sites and in agriculture. ${ }^{29}$

Although casual labour met the requirements of some branches of industry, as a mode of working and living it was at odds with social norms widespread since the late nineteenth century, which took for granted that regular work had a higher educative and social value. However, as Michael Gruittner has shown for Hamburg dockworkers, casual labour had its attractions for many workers. It gave young single men in particular the scope to lead a more self-determined life within certain limits, characterized by individual control over their allocation of working time and leisure time. ${ }^{30}$ This attitude to work was found particularly among British dockers, but also among American dockworkers. ${ }^{31}$ The Mississippi River roustabouts in New Orleans, casual labourers who handled riverboats, are a classic example. In 1901 a captain made the disillusioned comment that "As long as they have a dollar left there is no Mr. Roustabout at the plank ready to go". The casual work habits had a resurgence during the First

Protective Union (LSPU), 1890-1914", Labour/Le Travail, 26 (1990), pp. 37-59, esp. p. 59.

${ }_{29}$ See Gruttner, Arbeitswelt, p. 34; Prusse, Seemannsberuf, p. 75; Rosenberg, New Orleans Dockworkers, p. 47; Kimeldorf, Reds or Rackets?, p. 20f.; Peter Way, Common Labour. Workers and the Digging of North American Canals 1780-1860 (Cambridge, 1993), p. 271; Robert H. Babcock, "Saint John Longshoremen during the Rise of Canada's Winter Port, 1895-1922", Labour/Le Travail, 25 (1990), pp. 15-46, esp. p. 23. See also Carville Earle, "Divisions of Labor: The Splintered Geography of Labor Markets and Movements in Industrializing America, 1790-1930", International Review of Social History, 38 (1993), Supplement 1, pp. 5-37. Earle argues for an intermediate level of investigation between national and regional analysis.

${ }^{30}$ The lifestyle of casual labourers in Germany has been critically examined by: Gruttner, Arbeitswelt, esp. pp. 192-201; idem, "Arbeiterkultur versus Arbeiterbewegungskultur. Oberlegungen am Beispiel der Hamburger Hafenarbeiter 1888-1933", in A. Lehmann (ed.), Studien zur Arbeiterkultur (Münster, 1984), pp. 244-282; and from a supraregional viewpoint, idem, "Die Kultur der Armut", in Heinz Gerhard Haupt et al. (eds), Armut und Ausgrenzung. Jahrbuch Soziale Bewegungen, vol. 3 (Frankfurt and New York, 1987), pp. 12-32.

${ }^{31}$ On Britain, see Phillips and Whiteside, Casual Labour, passim; Sam Davies, "Three on the Hook and Three on the Book'. Dock Labourers and Unemployment Insurance between the Wars", Labour History Review, 59 (1994), part 3, pp. 34-43. On the quote, see Arnesen, Waterfront Workers of New Orleans, p. 105. 
World War. Although there are no comparative studies for other trades, it may be assumed that dockworkers' behaviour went beyond the isolated incidents of indiscipline that were to be found in other occupations during economic booms. Thus during the war years with high levels of employment many New Orleans dockworkers only worked three or four days per week, sometimes even just two or three night shifts. Then they took a break until their earnings had run out. ${ }^{32}$ These workers were not primarily interested in permanent employment; they only started looking for a job again when they needed money. From the company viewpoint, carrying on with casual working was problematic for two reasons. First, the amount of work done by these casual workers was relatively low. Second, their lack of commitment to one company led to constant disputes, since the casual labourers had practically nothing to lose apart from a short-term job. If they were dismissed, they could find other employment, at least when the economy was running well. ${ }^{33}$

In the port of Hamburg the move away from casual labour, linked to the creation of a centralized labour exchange controlled by the port employers, was pursued consistently from the start of the twentieth century. To this end the port and shipping companies had joined together in 1906 under the leadership of the great Hamburg-America Line (HAL) to form the HBV. In 1925 this association comprised 890 companies. $^{34}$ At the core of the labour-market organization, which was almost certainly unique in international terms, were the HBV's hiring halls and work card. This system divided each of the harbour trades into three groups: regularly employed workers, irregular card-holding workers and casual workers. While the regular workers were permanently employed by a specific company, the irregular card-holding workers were moved about from one company to the next depending on the amount of work available. As a rule, they did have work on several weekdays, but they had neither a fixed workplace nor any guaranteed entitlement to employment. The casual workers were employed without a card. They could only hope for work if the supply of regular employees and card-holders was insufficient. By the beginning of the First World War, the employers' monopoly of power on the labour market had been consolidated in this structure. The uncoordinated hiring of labour by middlemen, often conducted in harbour bars, was greatly reduced in importance by the HBV's labour exchange. However, at times, particularly during the high employment of the inflation years 1921 to 1923 but also during the economic crisis, there was a resurgence in taking on labour from the streets, what was known as "wild" labour

\footnotetext{
32 See Phillips and Whiteside, Casual Labour, p. 227.

33 See Gruttner, Arbeitswelt, p. 246f.; and on the following, see ibid., esp. ch. IX; Klaus Weinhauer, "Arbeitsmarktorganisation im Hamburger Hafen 1906-1951", in Herzig and Trautmann, "Der kilhnen Bahn nur folgen wir...", pp. 269-295, esp. pp. 270-273.

34 See Carl von During, Die Organisation der Arbeit im Hamburger Hafen (Hamburg, 1925), p. 16.
} 
provision carried out by the foremen or Vizen ("seconds-in-command"). Thus the HBV was not in a position to enforce its organizational guidelines on all companies or it had no interest in doing so.

The division into regular and irregular workers is not a development peculiar to dock work. Alongside divisions by nationality, it was the main dividing line in the working and living habits of American lumberjacks. The high turnover typical of this occupation resulted principally from the high mobility of the casual labourers. ${ }^{36}$ In the port of Hamburg the organization of the labour market adopted by the HBV at the beginning of the twentieth century had very extensively eroded the casual labour mentality by comparison with British ports. ${ }^{37}$ Although some casual workers continued to be employed into the mid-1920s, they were only a marginal phenomenon in dock transport after 1928-1929. However, the irregular card-holding labourers retained remnants of the loose work discipline characteristic of the casual labourers. Particularly in periods of economic prosperity, picking and choosing work and absenteeism from the allotted job were frequent occurrences. ${ }^{38}$

The HBV system was overstretched by the world economic crisis. From 1930 on, work opportunities for the irregular card-holders were drastically reduced. For example, in the last quarter of 1932 - normally a period of high employment - the irregular dockers were only able to work three shifts per week on average, and the quayside workers even less, only around one shift. ${ }^{39}$ The potential for conflict represented by the many irregular dockworkers without employment forced a search for new methods of organizing the labour market. However, major change was brought about only by the measures imposed by the National Socialists. Two aspects were central: first, irregular dockworkers were more closely tied to the dock companies and the number of regular jobs were also increased; second, the dock labour market could now be better controlled since it had been completely centralized. These socio-political measures served to reduce the mobility of the dockworkers and therefore their conflict potential, while also securing the companies a supply of experienced and motivated labour.

The reorganization of the labour market was pushed through purposefully in the early years of National Socialist rule. The National Socialist Factory Cells Organization (Nationalsozialistische Betriebszellenorgani-

\footnotetext{
${ }^{35}$ See Hamburger Echo, no. 63, 5 March 1923.

${ }^{36}$ In his diaries on Californian itinerant workers for June 1914, Frederic C. Mills characterized the different lifestyles of relatively regularly employed and casually employed lumberjacks. See Gregory Woirol, In the Floating Army. F.C. Mills on ltinerant Life in California, 1914 (Urbana and Chicago, 1992), p. $58 \mathrm{f}$.

${ }^{37}$ Svend Aage Andersen overestimates the continuity of the casual worker mentality, at least for Hamburg; see his Dockers' Culture, p. 24.

${ }^{38}$ See Weinhauer, "Zwischen Betrieb", p. $16 \mathrm{f}$.

${ }^{39}$ Düring, Gesamthafenbetrieb, pp. 68 and 70.
} 
sation, NSBO) played an important role in the process. ${ }^{40}$ The NSBO, the port companies and HBV representatives reached an agreement at the beginning of July 1933 to eliminate the "free selection" of labour in stevedoring, the branch giving rise to the most disputes. The registered dockers were allocated to particular companies in the individual labour exchanges, and were allotted work by numbers." The distribution of jobs was no longer in control of the foremen but went according to the number on the work card. However, this innovation affected only those dockworkers who had survived the social and political selection process associated with the reorganization. By comparison with December 1932, the number of irregular card-holding workers had been reduced by more than a quarter one year later. ${ }^{42}$ Additionally, working hours for all dockworkers were limited initially to four shifts and seven hours overtime, and from the end of October 1933 to five shifts per week. This also applied to the regularly employed dockworkers, and gave rise to dissatisfaction in their ranks. Their disappointment at such a cut may have been all the greater because, at least according to a communist source, 50 to 60 per cent of them had already joined the NSBO ${ }^{43}$ The protest from the regular workers could be tolerated, though, since the employment situation of the main target group for the reorganization, the irregularly employed workers, had been improved. Thus, the dockers worked an average of 4.5 shifts per week in 1935 , and the quayside workers on average 4.8 shifts. $^{4+}$

The HBV and the port companies had initially fought vehemently against the abandonment of "free selection" as they feared an irreversible decline in work performance. These initial doubts were dispelled from the companies' viewpoint because even without "free selection", dockworkers' willingness to work was now controlled by constant reports submitted by all companies. Furthermore, this discipline- and performancepromoting function was centrally supported by the NSBO Port Works Council. ${ }^{45}$ When it saw the prospect of a total labour-market monopoly over the irregular dockworkers, to which even hitherto non-cooperating

${ }^{40}$ It is very much disputed in German research circles whether this organization is to be regarded as a trade union-like institution. See the summary in Tobias Mulot, "Von der Betriebszelle zur Arbeitsfront. Die Hamburger NSBO auf dem Weg in die 'Leistungsgemeinschaft' des Dritten Reiches", in Frank Bajohr and Joachim Szodrzynski (eds), Hamburg in der NS-Zeit. Ergebnisse neucrer Forschungen (Hamburg. 1995), pp. 203-230. The NSBO began losing infuence to the DAF by 1934 at the latest. For the relationship between NSBO and DAF, see ibid., p. $208 \mathrm{f}$.

4 "Der erste Hafenbetriebsrat im Dritten Reich. Ein Bericht" (Hamburg, 1934), p. 27. On what follows, see Weinhauer, Alltag, p. $340 \mathrm{f}$.

12 Calculated according to the Statistisches Jahrbuch der Freien und Hansestadt Hamburg 1932/33 und 1933/34 (Hamburg, 1933/1934), p. 80 in each case.

${ }^{43}$ Stiftung Archiv der Parteien und Massenorganisationen im Bundesarchiv, Zentrales Parteiarchiv $1 / 3 / 16 / 66$, sheet 130 .

4 See During, Gesamthafenbetricb, p. 68.

4 See "Hafenbetriebsrat", p. 28. 
companies would have to submit, the HBV quickly forgot its initial scepticism. Irregular workers' willingness to work and their attitude towards work were subject to much greater control in this centralized labour market. Additionally - another important point - the HBV extended its control of the labour market by bringing the foremen into its work card system. ${ }^{46}$ Having themselves been subjected to a selection process, these "NCOs of the docklands" lost their previous almost unlimited power. In May 1934 all the private dock companies were combined in the Hamburg Joint Dock Company (Gesamthafenbetrieb Hamburg). The individual companies remained independent, but the joint dock company became the employer of the irregular card-holders. The regular employees of the individual companies were now referred to as "individual dock company workers". By the end of 1937, 53.5 per cent of the workers in the Hamburg Joint Dock Company were regularly employed. ${ }^{47}$ Not least with reference to the state of near civil war provoked by a dockworkers' strike in San Francisco in the summer of 1934, the head of the Hamburg Joint Dock Company, Carl Freiherr von Düring, judged the joint dock form of organization to be "the only possibility for bringing lasting peace to the docks".

The concept fundamental to labour-market conditions in many US docks was the "shape-up". ${ }^{48}$ In this system, the hiring of labour was in the control of foremen commissioned by intermediary firms (stevedores) or directly by the shipping lines to find the necessary workers. ${ }^{49}$ The shape-up remained predominant into the Second World War, particularly in New York, by far the largest seaport in the country. In this huge labour market, with its individual docks such as Manhattan and Brooklyn, workers were obliged to offer their labour to the foremen at fixed times. They were then selected on dubious criteria. A similar situation was to be found in many British ports. ${ }^{30}$ In theory, after 1916 members of the International Longshoreman's Association (ILA), the New York dockworkers' trade union, were supposed to have priority in employment

${ }^{4}$ On the following quotations, see Düring, Gesamthafenbetrieb, pp. 54 and 30.

${ }^{47}$ See Statistisches Jalirbuch der Freien und Hansestadt Hamburg 1937/38 (Hamburg, 1939), p. 76.

${ }^{48}$ See the still important survey by Charles P. Larrowe, Shape-Up and Hiring Hall. A Comparison of Hiring Methods and Labor Relations on the New York and Seattle Waterfronts (Berkeley and Los Angeles, 1955); for a summary for the United States, see David Montgomery, The Fall of the House of Labor. The Workplace, the State, and American Labor Activism (Cambridge [etc.], 1987), pp. 96-116.

${ }^{49}$ On the middlemen in New Orleans, see Amesen, Wateffront Workers of New Orleans, pp. 21f. and 40; John R. Commons, "Types of American Labour Unions: The Longshoremen of the Great Lakes", Quarterly Journal of Economics, 20 (1906), pp. 59-85 and 61. so See Larrowe, Shape.Up and Hiring Hall, p. 15; on San Francisco, see Nelson, Workers on the Waterfront, p. 106f. See also Edward E. Swanstrom, The Waterfront Labour Prob. lem. A Study in Decasualization and Unemployment Insurance (New York, 1938), p. 27f.; and for Britain, see Phillips and Whiteside, Casual Labour, passim. 
in the local docks. However, there were no binding maximum upper limits for the number of union members employed, nor were there any other limitations on membership such as high entry dues. Accordingly, the shape-up was basically available to anyone who joined the union. ${ }^{51} \mathrm{~A}$ report by a contemporary journalist of the difficulties faced by a San Francisco dockworker looking for work under the shape-up system was also true of New York, but would have applied to Hamburg before 1934 too: "His 'luck' depended on a number of factors. Does some hiring boss have special favor for him? Has he been able to find a hiring boss willing to take a kick-back for every day's work? Has he been able to befriend a hiring boss through an occasional bottle of liquor, or through such little services as painting or repair work on his house?"52 With such an irregular distribution of employment opportunities, characterized by favouritism and bribery, some workers had to do overtime until they dropped while others were left with no work at all. And in the docks of the US South such as New Orleans competition on the labour market was further intensified by the possibility of playing off whites and blacks against each other. ${ }^{53}$

The world economic crisis also worsened the employment situation in the US ports, and brutal scenes occurred during the hiring of workers. Thus, on the oversaturated labour market of the New York ports "competition for jobs turned morning shape-ups into near riots". ${ }^{44}$ In view of the high unemployment and the fierce competition for the few jobs to be distributed, it is worth asking how these labour-market problems were solved. Despite the economic crisis and the rise of the trade union movement under the New Deal, very little actually changed in the allocation of labour in New York until the Second World War. ${ }^{\text {s5 }}$ The corruption of ILA branches, ${ }^{56}$ a labour market deeply divided along lines of nationality, and the physical separation of the dockworkers in their various quarters of the city, to mention only some of the factors, prevented any fundamental reorganization of the labour market there.

\footnotetext{
st See Kimeldorf, "Social Origins", p. 344.

32 Quoted from Andrew Bonthius, "Origins of the Intermational Longshoremen's and Warehousemen's Union", Southern California Quarterly, 59 (1977), pp. $379-426$ and 380. Cf. also a quotation by Harry Bridges, in Joseph P. Goldberg. The Maritime Story: A Study in Labor-Management Relations (Cambridge, 1958), p. 133.

s3 "Longshore Labor Conditions", p. 1055. See also Larrowe, Shape-Up and Hiring Hall, pp. 54-59. In New Orleans cooperation between white and black dockworkers' unions helped at least at times to moderate the negative consequences of this division. Under the umbrella of the Dock and Cotton Council formed in 1901, work was distributed equally between members of the two organizations. However, these achievements were reversed by the employers during the post-war depression. See Amesen, Waterfront Workers of New Orleans, pp. 237-252; Rosenberg, New Orleans Dochworkers, pp. 170-174.

s4 Kimeldorf, Reds or Rackets?, p. 92.

ss On the following, see ibid., pp. 120-125 and 152-156; quote on p. 152.

so See ibid., p. 120f., and also John Hutchinson. The Imperfect Union. A History of Corrup. tion in American Trade Unions (New York, 1970), esp. pp. 93f.
} 
On closer examination, however, the dock labour force was not a completely unstructured, fluctuating mass even in the ports characterized by shape-up. Here, too, although there were only a few regularly employed dockworkers, there were other looser links to dock work. In the New York ports, for instance, there were informal groupings, the hiring clubs, whose foremen hired only club members in return for a fixed monthly payment. ${ }^{37}$ There was also a link to particular companies through the steady gangs, which were taken on preferentially by individual firms, but without any guarantee of income. Nonetheless these internal groupings of dockworkers were too weakly developed for any successful collective action. Until the Second World War the very frequent changes in workplace and workmates made any on-the-job solidarity very difficult to achieve. Evidently this instability could not be offset by working in gangs, although from about 1942 onwards the upswing in employment resulting from the war brought about a gradual process of change. Regular work gangs were employed increasingly in order to raise efficiency, and towards the end of the war these made up two-thirds of the New York dock labour force. ${ }^{58}$ The favourable labour-market conditions and more stable group structures also improved the New York dockworkers' ability to act collectively. The New York ports were then crippled by strikes until the early 1950s, and the ILA increasingly lost support among the dockworkers, until in 1953 government-controlled hiring halls were introduced. ${ }^{39}$

In contrast to the New York docks, the West Coast had large, influential shipping companies which had been pushing developments in the direction of a centralized labour allocation since the 1920s. The well-organized employers' camp was dominated by the "Big Three" (Matson, AmericanHawaiian, and Dollar Line). ${ }^{60}$ They were strong enough to be able to enforce their plans. This provided a major impetus for the reduction of casual labour and the centralization of the dock labour market. In Hamburg this role fell primarily to the powerful Hamburg-America Line. Its managing director, Albert Ballin, played a central part in the process until $1918 .^{61}$ By contrast, the heterogeneous structure of the dock companies in New York and in the British ports precluded a common employers'

37 See Larrowe, Shape-Up and Hiring Hall, p. 55. The development of permanent job opportunities after 1953 is described by Vernon H. Jensen, "Hiring Practices and Employment Experiences of Longshoremen in the Port of New York", International Labour Review, 77 (1958), pp. 342-369, 351f. and 357.

38 On the following and on the quotation, see Kimeldorf, Reds or Rackets?, p. 152.

${ }^{39}$ On New York, see Larrowe, Shape-Up and Hiring Hall, esp. pp. 184-205; Jensen, Hiring of Dockworkers, esp. pp. 30-85.

60 See Kimeldorf, Reds or Rackets?, pp. 55-79.

61 See Gruttner, Arbeitswelt, p. 222f.; on Ballin, see Frank Broeze, "Albert Ballin, the Hamburg-America Line and Hamburg. Structure and Strategy in the German Shipping Industry", Deutsches Schiffahrtsarchiv, 15 (1992), pp. 135-158; idem, "Shipping Policy and Social Darwinism: Albert Ballin and the 'Weltpolitik' of the Hamburg-America Line 1886-1914", The Mariner's Mirror, 79 (1993), pp. 419-436. 
approach. As Howard Kimeldorf has put it, "the ports' lack of capital concentration created a leadership vacuum at the top". ${ }^{62}$ In addition, the New York shipping lines had no common economic basis; instead fierce competition developed between local private lines, government companies and foreign firms such as the HAL. In such ports, small companies frequently had reason to make separate agreements with workers and trade unions. ${ }^{63}$

Beside the intention of increasing labour productivity, the dock and shipping companies had the aim of "driving the union from the docks". This was done in San Francisco by forming a union with close links to the employers, the Blue Book Union. Employers gave its hand-picked membership priority when taking on labour, although the shape-up continued to exist alongside it. Centralized hiring halls were set up in Seattle in 1921 and in Portland in May 1922. The American slang term for these agencies was "fink halls"; they were controlled exclusively by the employers without any participation by the ILA. In Seattle there were now "company gangs" working regularly for one company, "hall gangs" or "reserve gangs" working for a variety of employers, and still a small number of "casual men" who found work only occasionally. After this transfer of power a report from Portland stated: "Working conditions on the docks were dramatically transformed as control over hiring passed from the union to the employers. With the men toiling under an immense speed-up, numerous port production records fell: one non-union crew, for example, stowed 38,000 sacks of flour in one fifteen-hours shift, averaging 63 tons per hour as compared with 40 to 52 tons per hour before the strike". ${ }^{\circ}$

When work allocation was controlled by the employers in this way, both the structure and the attitude to work of the dock labour force was transformed. As regards the structure, the companies made efforts to employ mainly married and settled men while sifting out all the previous casual workers and trade unionists. For instance, of 1,200 registered workers in San Pedro, 80 per cent were married and 50 per cent had a house of their own. ${ }^{66}$ Although there are no exact comparative figures for the earlier period, it may be assumed that these proportions are vastly

${ }^{62}$ Kimeldorf, Reds or Rackets?, p. 78; on the British ports, see Phillips and Whiteside, Casual Labour, pp. 283-286.

${ }^{63}$ See Kimeldorf, Reds or Rackets?, pp. $67 f$. and 78 (on New York); Arnesen, Waterfront Workers of New Orleans, p. 165 (on New Orleans); Amesen, "Race Relations, Labor Markets", p. 71f. (on Galveston).

${ }^{64}$ Kimeldorf, Reds or Rackets?, p. 77; on the following, see "Longshore Labor Conditions", pp. 1059-1063; William W. Pilcher, The Porlland Longshoremen. A Dispersed Urban Conmunity (New York [etc.], 1972), p. 31f.; Larrowe, Shape-Up and Hiring Hall, pp. 91-94 (on Seattle); Kimeldorf, "Social Origins", pp. 332-342; Nelson, Workers on the Waterfront, pp. 103-106 (on the Blue Book Union).

${ }^{65}$ Kimeldorf, Reds or Rackets?, p. 32.

${ }^{6}$ See Kimeldorf, "Social Origins", p. 338; Larrowe, Shape.Up and Hiring Hall, p. 92f. 
different from the times when mostly casual labour was employed. As for attitude to work, as the example of Portland shows, the workers who were now regularly employed developed closer ties to the company and no longer regarded themselves simply as dockworkers but as employees of their firm. ${ }^{67}$ However, the casual labour mentality did not vanish overnight, as even the "gang-men" with employment priority frequently took days off. $^{68}$

On the West Coast, stable union-controlled labour markets came into being after the wave of strikes in 1934-1936. ${ }^{69}$ The pathbreaking success of the strike in May-July 1934 resulted from a number of factors. ${ }^{70}$ First, the dockworkers and seamen acted together, overcoming traditional occupational barriers, and showed great determination. Second, the leadership was distanced from the tradition of the reformist American Federation of Labor (AFL) and its forms of action, and enjoyed the trust of the waterfront workers. This applied particularly to its charismatic leader, Harry Bridges. Together with some other undogmatic communist colleagues, many with a syndicalist background, Bridges had abandoned the official Communist Party (CP) line since the early 1930s. They did not form an independent union but instead worked within the ILA. Their newspaper, the Waterfront Worker, was held in particularly high esteem by the seamen and dockworkers.

After the summer 1934 strike, the hiring halls were run jointly with the employers. ${ }^{\text {" }}$ The San Francisco docks illustrate how this worked in practice. The trade union (from summer 1937 the International Longshoremen's and Warehousemen's Union, ILWU) and the employers had drawn up a list of workers employed in the docks for several years, and these were now "registered men" who were to be employed regularly. These

67 See Pilcher, Portland, pp. 23 and 35 f.

6s See ibid., and Michael Torigian, "National Union on the Waterfront. Communist Politics and the ILWU during the Second World War", Labor History, 30 (1989), pp. 409-432. esp. 415.

69 Until the summer of 1937 this was the ILA. When the locals on the Pacific coast then split from the American Federation of Labor (AFL) and joined with the Congress of Industrial Organizations (ClO), the Intemational Longshoremen's and Warehousemen's Union (ILWU) was founded. See Kimeldorf, Reds or Rackets?, pp. 4 and 117.

${ }^{70}$ On the following, see Nelson, Workers on the Waterfront, pp. 120f. and 128; Kimeldorf, Reds or Rackets?, pp. 84-91; on Hanry Bridges, see Nelson, Workers on the Waterfront, pp. 139-142; Kimeldorf, Reds or Rackets?, p. 163f.

"On the following, see Lawrence M. Kahn, "Unions and Internal Labor Markets. The Case of the San Francisco Longshoremen", Labor History, 21 (1980), pp. 369-391 and 378-383; Herb Mills and David Wellman, "Contractually Sanctioned Job Action and Workers' Control. The Case of San Francisco Longshoremen", Labor History, 28 (1987), pp. 167-195 and 174-190; Kimeldorf, Reds or Rackets?, p. 111f. The almost identical job distribution systems in Seattle and Portland are described by Larrowe, Shape-Up and Hiring Hall, pp. 62-65; Pilcher, Portland, pp. 139-153. Rotational hiring was not restricted to seaports; for the Memphis river docks, see Michael K. Honey, Southern Labor and Black Civil Rights. Organizing Memphis Workers (Urbana and Chicago, 1993), pp. 104-113. 
" $A$ " men were all required to be union members. The second category of workers, the "permit men" or " $B$ " men, were also registered as dockworkers but did not necessarily have to be union members. They were taken on if there was more work than the registered union members could handle. The group of " $A$ " men was supplemented from the ranks of the " $B$ " men. On the lowest rung were the casual workers, neither registered or unionized, who were only taken on at times of peak demand. In 1937 the registered men made up between 75 per cent and 90 per cent of the workers. $^{72}$

There were three factors which from 1934-1936 onwards broke the employers' monopoly of power, ensured regular employment for registered unionized dockworkers, and stabilized trade union organizations. First, the number of hours worked became the major criterion for work allocation. The "low man out" or "low gang out" system ensured that those who had so far worked the fewest hours would have the first chance of employment. ${ }^{73}$ Second, the settlement announced by the National Longshoreman's Board on 12 October 1934 made no provision for disciplining dockworkers. Although a company could dismiss workers it was unhappy with, they went straight back into the body of registered dockworkers. Workers disciplined in this way could go straight back to work when it was their turn. A dockworker could not be removed from the register except for drunkenness or serious theft. Third, although the union and the employers jointly ran the employment agencies, the selection of workers was carried out by an employee, the dispatcher, who was elected annually from union circles. So now "The hiring hall was indeed 'the union" ".74

The agreements of October 1934 and July 1937 settled two other points which in previous years had been principally responsible for growth in port turnover being achieved at the expense of the dockworkers. ${ }^{75}$ The weight of goods moved per winch load and the numbers in the work gangs were laid down contractually. These world-renowned privileges of the San Francisco ILWU dockworkers were not lost again until the late 1950s. In particular, the first agreement on "Mechanization and Modernization" concluded for 1961-1966 opened the way to a hitherto unknown exploitation of the workforce. ${ }^{76}$ The abandonment of equal work distribution and

7 See Kahn, "Unions and Internal Labor Markets". p. 371.

${ }^{73}$ For this system, see Herb Mills, "The San Francisco Waterfront. The Social Consequences of Industrial Modemization", Part One: "The Good Old Days", Urban Life, 5 (1976), pp. 221-250 and 229f., and the same author's "The San Francisco Waterfront. The Social Consequences of Industrial Modemization", in Andrew Zimbalist (ed.), Case Studies on the Labor Process (New York and London, 1979), pp. 127-155 and 131.

"Mills, "The San Francisco Waterfront", p. 228.

is See Mills and Wellman, "Job Action", pp. 175-177 and 183-189; Kimeldorf, Reds or Rackets?, p. 112f.; Nelson, Workers on the Waterfront, p. 159f.

${ }^{76}$ For surveys, see Fairley, Facing Mechanization: Paul T. Harman, Collective Bargaining and Productivity. The Longshore Mechanization Agreement (Berkeley and Los Angeles, 1969). 
accelerated mechanization deprived these dockworkers of their previous rights of co-determination.

The rights obtained by the unionized dockworkers of San Francisco, as examined above, cannot be interpreted as an unqualified success story. The ILWU members' monopoly on employment was achieved by sealing off the labour market to the outside. Against the background of economic depression and unemployment, union members secured themselves a segment of the labour market by excluding their non-unionized colleagues. ${ }^{77}$ This far-reaching reorganization of dock work was in general a contractually-secured mixture of fragmentation and concessions. On the one hand, the splitting of the dock labour force into preferentially employed and hence high-earning union members and casually employed irregular workers had been confirmed. On the other hand, the trade union had won a role in the organization of the labour market and the shaping of working conditions, but also became partly responsible for these. However, a labour market monopoly of this kind is only effective if the trade union concerned is strong enough to ensure that what has been agreed is put into practice. In the port of Hamburg there were violent clashes with union dockworkers in spring 1920 when the social-democratic DTV tried unsuccessfully to introduce a similar labour market plan. ${ }^{78}$

Furthermore, these organizational measures adopted in the US West Coast ports and the change in the attitude to work over the longer term represented two major steps in the removal of traditional sources of tension. First, the dispute-prone casual labourers had been largely excluded from dock work. Second, it became clear how central a role the organization of the labour market played for the standards and values of the dockworkers. As shown above, in the 1920s the employers' hiring halls had given rise to closer links between the workers and the companies; a kind of company-related corporate identity had developed. As retrospectively noted in a cultural anthropological study of Portland dockworkers, these links dissolved again when rotational hiring was brought in: "They never identify their occupation by saying that they work for some company or other. When questioned about their occupation by outsiders, they answer that they are longshoremen, that they work on the waterfont, or that they are nembers of the ILWU."79

But even after 1934 employers on the West Coast could safely assume that the labour performance of union members had not fallen off excessively. This was ensured partly by the limitations on the pool of labour and the resulting regular employment for those organized in the union, and partly because the work ethos took on a new orientation. Now as a

\footnotetext{
"Kahn, "Unions and Internal Labor Markets", p. 383, comes to the same conclusion: "[...] after the 1934 and 1937 agreements, longshoring in San Francisco had been trans. formed into a high-income, steady job for union members".

73 See Weinhauer, Alliag, pp. 209-212.

79 Pilcher, Portland, p. 23.
} 
rule the talk was of a "working union": that is, a good dockworker and trade unionist does good work. ${ }^{80}$ There was also the expectation that every member of a gang should do his share of the work since otherwise the extra work would have to be done by another member of the gang. A code of honour had also developed among West Coast dockworkers since the mid-1930s, with the slogan "meet the hook";81 the workers regarded it as normal to work so fast that the ship's winch with its loading hook did not have to stand still for too long. In retrospect, even the employers had to admit that "[...] the hiring hall [...] has the effect of improving the character of the men themselves; because it gives them greater stability of employment and earnings, it gives them dignity". ${ }^{22}$

\section{HARBOUR DISTRICTS, SYNDICALISM, DIRECT ACTION}

Recent studies constantly point to the importance of the harbour districts of towns for dockworkers and seamen. ${ }^{83}$ Before going on to consider the rise of syndicalist organizations in more detail, I should therefore first like to consider Hamburg as an example of the factors which caused these districts to become so special, both in a local context and from an international viewpoint. There were similar districts in the British and the New York ports, whereas San Francisco lacked a district of this kind. ${ }^{84}$ The extent of the Hamburg harbour milieu cannot be delimited precisely. First, it is characterized by its physical closeness to the workplaces in the docks. Because ship arrivals were unpredictable, it was important for dockworkers to live as close to the docks as possible so that they could turn up quickly when jobs were to be distributed. Living in this area also saved fares for public transport because of the short distance to work. However, it frequently also meant living in crowded near-slums.

Second, the harbour district was characterized by a tight-knit communications network. Its central exchanges, aside from the residential areas

${ }^{* 0}$ David Wellman, The Union Makes Us Strong. Radical Unionism on the San Francisco Waterfront (Cambridge, 1995), p. 183.

"See Mills and Wellman, "Job Action", p. 185.

"Larrowe, Shape-Up and Hiring Hall, p. 162.

is See Nelson. Workers on the Waterfront, p. 15f., and the graphic description of the communications structures in British docklands in the inter-war years in Laura Tabili, "We Ask for British Justice". Workers and Racial Difference in Late Imperial Britain (thaca and London, 1994), pp. 135-160.

34 See Kimeldorf, Red's or Rackets?, p. 13f.; and on housing conditions in some streets of the Manhattan harbour district in New York, see Elizabeth Ogg, Longshoremen and Their Homes. The Story of a Housing "Case" Study Conducted Under the Auspices of Greenwich House (New York, 1939), esp. pp. 40-48; Dock and Harbour Authority, 10, 120 (1930), p. 387; also Gareth Stedman Jones, Outcast London (Oxford, 1971); on Hamburg, see Gruttner, Arbeitswelt, ch. V.2; Weinhauer, Alltag, ch. I.6; on forms of action in workers' residential areas, see also Weinhauer's "Konfikte am Arbeitsplatz und im Milieu: Perspektiven einer sozialgeschichtlichen Erforschung von Arbeitskimplen und Konsumentenprotesten im 20. Jahrhundert", Archiv fir Sozialgeschichte, 38 (forthcoming, 1998). 
themselves, were the bars and the various hiring halls. This network made it possible for the dockworkers, scattered during the working day over various ships, quays and piers, to tell each other what was happening and work through their collective experiences. During strikes the "debating clubs" 85 of the Hamburg dockworkers met in the public streets and squares of the neighbouring city districts. All this strengthened the dockworkers' capacity to act collectively. Thus strikers would attack strike-breakers in their residential districts before they had even gone to their workplace. ${ }^{86}$ During the New York dock strike of October 1919, for instance, the IWW managed to gain influence gradually by its presence at the many strike meetings in the districts around the harbour ${ }^{87}$ although it had previously had little support either in the labour market or in the workplace. In many US ports the districts near the harbour were also the places to find out when work might be distributed ${ }^{88}$ Later the labour exchanges had a prominent role as communication centres. This was particularly true of the trade union agencies. On the West Coast of the United States after 1934-1936 "[...] the hiring hall was also crucial as a place to relax and talk. It was a community center in the deepest sense of the term". ${ }^{89}$

Even although comparable details are not available for other cities, the example of Hamburg shows that the simple existence of these bars did not of itself have an integrative and solidarity-promoting effect. Nor did they form enclaves of resistance to all the processes of change. With the formation of the communist "Unified Association of Seafarers, Dockworkers and Inland Waterway Workers" in February 1931, communist-oriented union supporters met in different bars from their social democratic fellow workers. ${ }^{90}$ In view of the current state of research it is still unclear to what extent this involved the consolidation of pre-existing informal divisions and subcultural milieus or the creation of new ones.

ss Hamburg State Archive (StAHH), Polizeibehörde II works signature 674, report of the Alstadt district, Precinct 8, 26 October 1928 (copy). The way in which Parisian cafés used to bring together groups of workers from separate workplaces is described by Roger Magraw, "Paris 1917-20: Labour Protest and Popular Politics", in Chris Wrigley (ed.), Challenges of Labour (London and New York, 1993), pp. 125-148, esp. 140; also Nelson, Workers on the Waterfront, p. 24.

${ }^{36}$ See Grultner, Arbeilswelt, p. 248; Weinhauer, "Zwischen Betrieb", p. $19 f$.

of See Calvin Winslow, "On the Waterfront: Black, Italian and Irish Longshoremen in the New York Harbour Strike of 1919", in John Rule and Robert Malcolmson (eds), Protest and Survival. The Historical Experience (London, 1993), pp. 355-393, esp. 361, 384 and 387.

${ }^{88}$ See "Longshore Labor Conditions", p. 813.

39 Mills and Wellman, "Job Action", p. 192. On the New York port of Brooklyn, see Di Fazio, Longshoremen, ch. IV, and also his "Hiring Community on the Brooklyn Waterfront", in Vernon Boggs, Gerald Handel and Sylvia F. Fava (eds), The Apple Sliced. Sociological Studies of New York Ciry (South Hadley, 1984), pp. 50-66; also Larrowe, Shape-Up and Hiring Hall, p. 140.

${ }^{90}$ See Weinhauer, Alltag, p. 165. 
Such a physical delimitation of the bars in which these groups met marks an admittedly small but still important dividing line running through the harbour district in the final stages of the Weimar Republic. The districts around the docks of many US ports were additionally criss-crossed by ethnic boundaries. Thus in New York Italian, Irish and Black dockworkers all lived in separate quarters of the harbour areas. ${ }^{91}$

Third, reference must be made to an interaction which distinguished harbour districts from, for instance, the residential districts around the workplaces in mining areas. The workplaces in the docks appear to have been much less divorced from the everyday life of the surrounding residential areas than was the case with mining, for instance. ${ }^{92}$ Thus there were still a lot of people living in the harbour area, and children from the surrounding districts played and bathed there or spent some of their free time there. The freeport checks carried out by police and customs could do little to change this. Women also probably still came to the workplaces of their menfolk to bring them food, even though this practice was clearly less widespread than at the start of the century. On the other hand, the area . of town around the docks was in turn the scene of work-related events. As described, job distribution often took place in its streets and squares. All in all, no sharp dividing line can be drawn in this milieu between private matters and workplace matters. Furthermore, these were parts of Hamburg where left-wing parties won many votes. In the elections to the Reichstag in November 1932, for instance, the KPD obtained 41.0 per cent of the valid votes cast in the Hamburg district of Neustadt, close to the harbour, and in some streets between 60 and 70 per cent; the average for the whole state of Hamburg was around 22 per cent. ${ }^{93}$ This is an example of a left-wing milieu which even US seamen found very impressive. ${ }^{94}$

Directly after the First World War, many dock towns experienced a hitherto unknown rise in proletarian obstreperousness. The widespread theft, the passive resistance, the increase in direct action and the translation of the dockworkers' syndicalist mood into an organized form can only be explained $^{95}$ if these phenomena are considered as an expression of dock-

91 See Winslow, "On the Waterfront", p. $368 f$.

92 See Franz-Josef Briggemeier, Leben vor Ort. Ruhrbergleute und Ruhrbergban 18891919 (Munich, 1983); Karin Hartewig. Das unberechenbare Jahrzehnt. Bergarbeiter und ihre Familien im Ruhrgebiet 1914-1924 (Munich, 1993); for an intemational survey, see Klaus Tenfelde (ed.), Towards a Social History of Mining (Munich, 1991).

${ }^{93}$ See H. Sköllin (ed.), Statistische Mitteilungen itber den hamburgischen Staat, 30 (Hamburg, 1932).

See Nelson, Workers on the Waterfront, p. 29.

9s On the syndicalist organizations, sce Kimeldorf, Reds or Rackets?, pp. 19f., 27-37, 4649; idem, "Social Origins", esp. pp. 326-342 and 352-357; Lisa McGir, "Black and White Longshoremen in the IWW: A History of the Philadelphia Marine Transport Workers Industrial Union Local 8", Labor Histon;, 36 (1995), pp. 377-402; IVeinhauer, Alltag, pp. 
workers' experiences of the power structure in the network of labour market, workplace and harbour area. ${ }^{96}$ This interaction can be traced clearly in Hamburg, although at this period in particular the widespread dissatisfaction of many dockworkers with their old union, the DTV, should not be forgotten. ${ }^{97}$ The low-profile policy adopted by the union in the war years, the way in which officials clung to their posts and their stalling tactics in response to the workers' radical demands, had shaken the workers' trust in the union with lasting effect. Even the successes achieved following the November 1918 revolution could do little to change that, and the eight-hour day introduced by the Stinnes-Legien agreement of 15 November 1918 was not enough to overcome the disillusionment and bitterness felt by many workers. I do not propose here to examine further the relationship between union membership and union leadership, a contentious subject particularly in British labour history, ${ }^{98}$ as it must be asked whether this does not divert attention from a proper consideration of what role unions actually played in workers' everyday thoughts and actions. Were the unions a central point of reference, and if so from when and for which workers, or were these organizations simply a means to an end? At least for the Hamburg casual dockworkers, the latter was true. If there was something to be achieved by, say, striking, they used the union. Otherwise, the union was rather on the fringe of their consciousness. This was indicated, for instance, by the low attendances at union general meetings until the end of the 1920s.99

Until the end of March 1919 there was hardly any work for the Hamburg harbour workers. This changed in two ways with the arrival of Allied food ships. In the first place it now became necessary to solve the still unsettled problem of job allocation, and here the HBV kept a very low profile. The dockworkers exploited this power vacuum. From June 1919, the few available jobs were divided up equally among the holders of work cards; no new cards were issued. The so-called "daily drop-out" system meant that every Hamburg docker could work for only one day and then had to wait for a new job allocation. ${ }^{100}$ Jobs were allocated in the sequence of the work card numbers. In this way, the labour market was reserved for the holders of work cards and partitioned off against the outside world.

197-203; Hartmut Rubner, Freiheit und Brot. Die Freie Arbeiter-Union Deutschlands. Eine Studie zur Geschichte des Anarchosyndikalismus (Berlin and Cologne, 1994), pp. 94-123; for the passive resistance and theft, see Weinhauer, "Zwischen Betrieb", p. 9f.

96 The interplay of social protest movement and industrial militancy as exemplified by the Ruhr miners is traced impressively by Hartewig, Jahrzehnt, ch. 8.

97 See Weinhauer, Alliag, p. $187 \mathrm{f}$.

9t On this discussion, see the contributions by Eric Amesen, James E. Cronin, Richard Hyman, Richard Price and Jonathan Zeitlin in International Review of Social History, 34/ 35 (1989/1990).

99 See Weinhauer, Alltag, p. 299; Gruttner, "Konfliktpotential", p. $155 f$.

100 See Hamburger Echo, 144, 27 March 1919; 280, 21 June 1919; 424, 13 September 1919. 
A similar model was found particularly in US West Coast ports, there described as "rotational hiring". In this case it was an attempt to use the continuing favourable trade situation as a buffer against the increase in work rate resulting from the war and the predictable consequences of the approaching economic collapse after the war. ${ }^{101}$ Second, in the spring of 1919 the Hamburg docks were not just a workplace again but also a place where, for dockworkers and large sectors of the population, scarce food supplies were close at hand in large quantities. By summer 1919, social protest movements in the form of the theft of food by large numbers of people, and the industrial militancy of the dockworkers, had formed an explosive combination. ${ }^{102}$

In these conditions, lasting until the spring of 1921, many irregular workers had developed great confidence in their own power and ability to enforce changes, a confidence supported by their working methods as described above and reinforced by the solidarity created by the method of job distribution ${ }^{103}$ This also influenced their attitude to work. These years between the summer of 1919 and the spring of 1921 were the golden age of syndicalism. In Hamburg this led to the establishment of the syndicalist "Allgemeine Arbeiter-Union" (General Workers' Union, AAU). After the revival in shipping in summer 1919 , the smouldering workplace disputes took on a political dimension. The irregular dockers in particular refused to accept the authority of the foremen and employers' representatives. This could not simply be integrated into the day-to-day routine of the docks; for instance, foremen's instructions were ignored, and there were also confrontations with police who had arrested some workers suspected of theft. ${ }^{104}$ The dockworkers also managed to evade the freeport checks by banding together in large groups. Thus, although the old organizational systems (job agencies, foremen) officially continued in being, it seemed as though the workplace, the labour market and the harbour districts were in sole control of the dockworkers. Additionally, from summer 1919 the presence of police, army and Free Corps carrying out checks at the freeport entrances promoted the radicalization of the dockworkers in two ways. The frequent conflicts demonstrated more than a general dislike of these units. In the first place there was a collision of very different norms and value systems. The traditional norms of justice in dock work were under attack. For instance, many dockworkers regarded it as perfectly natural to help themselves to small quantities of the cargoes for their personal use in this time of shortages, while the soldiers carrying out the checks

${ }^{101}$ See Kimeldorf, Reds or Rackets?, p. 29f.; Nelson, Workers on the Waterfront, p. $50 f$.

102 See StAHH Deputation fur Handel, Schiffahrt und Gewerbe (DHSG), II XXXIV 165f., report of the Greater Hamburg Workers' Council, 17 July 1919; ibid., 165e, DHSG Report 19 June 1919; Hamburger Echo, 276, 19 June 1919.

${ }^{103}$ On the following, see Weinhauer, "Zwischen Betrieb", pp. 10 and $13 f$.

104 See Hamburger Echo, 545, 24 November 1919; StAHH Arbeitsbehörde I 27, report of 1 December 1920; StAHH Arbeiterrat Groß-Hamburg, 3a vol. 1a, session of 18 June 1919. 
took a different view. ${ }^{105}$ Second, these checks operated as a further politicizing factor, a sort of daily lesson in the class struggle; they constantly reminded the dockworkers of their position in society, which was in stark contrast to the considerable power they enjoyed in their workplace and on the labour market, as well as in the harbour districts. These districts participated in the actions taken by the dockworkers, whether in short-term protests against excesses in the customs checks, or in full-scale strikes. It was there, for instance, that the public meetings of the syndicalist dockworkers, open to non-members, were held. Harbour employers too were faced with publicly presented demands supported by protest marches through the harbour districts. ${ }^{106}$

All these experiences make it understandable why such workers joined together in organizations which, with the individual company as their unifying base, proposed to restructure the existing social order fundamentally. In these organizations, the demands put forward and the organizational structure itself took completely different forms from what was typical of the German social-democratic labour movement. This development was encouraged by the fact that by this time the port was employing many workers who had not previously been socialized within the labour movement. Because of the increased transportation of Swedish ores since mid1915 , workers had repeatedly to be brought in from rural districts, frequently through newspaper advertising. ${ }^{107}$ The regularly employed workers not only held themselves back in these confrontations of the post-war years but actually tried to intimidate the irregular and casual workers and to uphold work discipline and the old power structures. ${ }^{108}$ Nor should all these observations create the illusion that dockworkers had everywhere and at all times demonstrated solidarity or class-consciousness; for example, there were isolated cases of Hamburg dockers bypassing the hiring halls and accepting work directly as early as mid-1919.109

The - real or only subjectively experienced - growth of industrial power described above, which reached a similar intensity in the US West Coast ports, ${ }^{110}$ does not necessarily result in the rise of radical left-wing unions. At least two other forms of behaviour can be imagined. For one, these experiences of the immediate post-war years could increase confidence in the power of collective action to such an extent that the support of any

\footnotetext{
${ }^{103}$ On harbour theft, see Michael Gruttner, "Working-Class Crime and the Labour Movement: Pilfering in the Hamburg Docks 1888-1923", in Richard J. Evans (ed.), The German Working-Class. The Politics of Everyday Life (London, 1982), pp. 54-79; Weinhauer. Alltag, ch. III.2.

106 See Hamburger Fremdenblatt, 444, 13 September 1920.

107 See StAHH Politische Polizei S 5900 vol. 1.

103 See StAHH DHSG II 165e vol. 2, report of the quay administration of 4 July 1919; Generalanzeiger fiir Hamburg Altona, 185, 10 August 1920.

${ }^{109}$ See e.g. Kommunistische Arbeiterzeitung, 27, 2 June 1919.

110 See Kimeldorf, Reds or Rackets?, p. 30f.
} 
external organization appears unnecessary. These workers would then remain unorganized. ${ }^{111}$ Such behaviour would be unsurprising, particularly in view of the live-for-the-moment attitude of many of the casual workers. Altematively, it would have been an obvious step for the dockworkers to carry on in their old organizations - the DTV in Hamburg and the ILA in the United States - rather than transferring to a new organization. ${ }^{112}$

Viewed internationally, the strong position of the syndicalist organizations had vanished by 1922-1923. In the US ports, as in other industries, employers launched an offensive against workers' post-war successes, and in particular against radical trade unions and their members. ${ }^{113}$ And from autumn 1920 the Hamburg HBV had taken a much firmer hold of the reins again with regard to labour-market organization. The syndicalist dock labour organizations started to lose their significance there by the spring of 1921. Contributory factors included the inflationary devaluation with its effects on the aims of workers' organizations, and the increased proportion of regular employment; but, above all, a new form of labour-market organization allowed far more scope for individual efforts to increase earnings. Dockworkers could now decide for themselves when they wanted to turn up for work and how many shifts they wanted to work, without any regard to collective agreements.

There was then no syndicalist-oriented movement of all the dockworkers either in Hamburg or in the US ports. Rather, the mobile, casuallyemployed workers played the predominant role. ${ }^{14}$ So this was no "revolt

"II Such behaviour motivated by personal considerations is discussed by Alf Ludtke, EigenSinn. Fabrikalliag, Arbeitererfahrungen und Politik vom Kaiserreich bis in den Faschismus (Hamburg, 1993).

${ }^{112}$ With regard to the latter point, the Dock and Cotton Council in New Orleans provided a framework flexible enough to give the necessary support to the demands of the dockworkers it represented. This was possibly the reason why the IWW could not win mass support there. Moreover, there is much to indicate that by comparison with other trades, particularly the freight handlers and roustabouts, the screwmen and longshoremen were relatively permanently employed and settled, with closer ties to the companies. As Eric Amesen concentrates his analysis on the latter two trades, he loses sight of the possibility that the IWW had its main support among the masses of itinerant workers among the railroad freight handlers and roustabouts; see Amesen, Waterfront Workers of New Orleans, p. 175f.; and on the railroad freight handlers and the Mississippi River roustabouts, see ibid., pp. 99 106. This thesis is supported indirectly by Bernard Cook and James R. Watson, "The Sailors and Marine Transport Workers' 1913 Strike in New Orleans: The AFL and the IWW". Southern Studies, 18 (1979), pp. 111-122 and 119f. The authors point to the high mobility and unsettled form of existence of the IWW members.

113 In addition to the studies already mentioned, see Nelson Van Valen, "Cleaning Up the Harbor': The Suppression of the I.W.W. at San Pedro, 1922-1925", Southern California Quarterly, 66 (1984), pp. 147-172; Herbert R. Northrup. "The New Orleans Longshoremen", Political Science Quarterly, 57 (1942), pp. 526-544; on Hamburg, see Weinhauer, Alltag, p. 209f., and "Zwischen Betrieb", p. 15f.

114 Kimeldorf, "Working-Class Culture", p. 367. Carleton H. Parker wrote: "[... ] the I.W.W membership in the West is consistently of one type, and one which has had a uniform economic experience. They are migratory workers currently called hobo workers": 
of the unskilled"115 supported in some cases by skilled workers. The communist dockworker movements which arose in the early 1930s showed a similar social composition. In Hamburg, for instance, the independent communist trade union, the Unified Association of Seafarers, Dockworkers and Inland Waterway Workers (Einheitsverband der Seeleute, Hafenarbeiter und Binnenschiffer, EVSHB), founded in February 1931, recruited its members predominantly from mobile casually employed groups of dockworkers, particularly from dockers and ship and boiler cleaners. These were trades which were employed mainly by small and mediumsized companies. Their fellow workers in the larger companies such as the HAL tended to keep their distance. ${ }^{116}$ The same kind of thing may be said indirectly of the communist trade union movement among US dockworkers, particularly in the West Coast ports, which gradually grew in strength after 1933. For instance, many Wobblies moved into the ILWU, and 50 per cent of the founder members of the communist Marine Workers Industrial Union (MWIU), founded in April 1930, were former members of the IWW. ${ }^{117}$

Despite the similar structural conditions, the New York dockworkers had no strong syndicalist or communist organizations. ${ }^{118}$ As well as the labour and labour-market conditions described above and the absence of a mobile workforce of seamen and lumberjacks, there were cultural traditions which stood in the way of such organizations; for instance the Italian dockworkers had their links to the padroni, fellow countrymen who provided them with work and accommodation, and to the Catholic Church. This was further reinforced by the division of the harbour areas by nationality; as shown above, this separation continued into the residential districts. ${ }^{119}$ In addition, the constant oversupply on the labour market smothered any large-scale protests and strikes, as did the largely comupt

Carleton H. Parker, The Casual Laborer and Other Essays (Seattle, 1972; original ed. 1920), p. 113f. The IWW sympathies of the Califomian itinerant labourers are referred to by Gregory R. Woirol, "Men on the Road: Early Twentieth-Century Surveys of Itinerant Labor in Califomia", California History, 70 (1991), pp. 192-205 and 201. On the social background of syndicalism in the port of Hamburg, see Weinhauer, Alltag, p. $200 \mathrm{f}$.

"15 Larry Peterson, "The One Big Union in International Perspective: Revolutionary Industrial Unionism 1900-1925", in James E. Cronin and Carmen Sirianni (eds), Work, Community and Power (Philadelphia, 1983), pp. 49-87, 81 (quote) and 73.

116 See Weinhauer, Alliag, pp. 316-335.

117 See Nelson, Workers on the Waterfront, p. 79. Characteristically, the leading proponents of an undogmatic communist trade union policy, including Sam Darcy and Harry Bridges, met in an assembly hall in the docklands district of San Francisco, the German-run Albion Hall. See Kimeldorf, Reds or Rackets?, pp. 37-49 and 120-126; on Albion Hall, see p. 87. For the strong position of the Wobblies among casuals see footnote 114 .

"18 See ibid., pp. 42-46. However, Winslow, On the Waterfront, p. 387, referring to the October 1919 strike, emphasizes a gradually growing influence, particularly among the Italian dockworkers in Brooklyn.

119 See Nelson, Workers on the Waterfront, p. 83. 
ILA locals. And Joe Ryan, the ILA president, was not only an extremely corrupt and conservative union leader, but also lacked the grass-roots support and charisma of such leaders as Harry Bridges. ${ }^{120}$

In any discussion of dockworker militancy, the focus is usually placed on a supposedly general tendency towards (often politically motivated) direct action. The prime example of this is the interruption of work produced by the "job actions" of the dockworkers on the US West Coast. ${ }^{121}$ However, to avoid inappropriate generalization, attention must be paid to important differences in the various countries. If direct action is taken to mean disputes which arise spontaneously in the workplace or in the labour market and are pursued without recourse to institutionalized procedures, then the definition applies to all the ports investigated here. Since ships had to leave harbour again in the shortest time possible, dockworkers had an effective weapon of stopping work or going slow to extort concessions from the employers. By this means minor successes or concessions for a particular trade could be obtained when a ship was waiting to sail. ${ }^{122}$ This tactic was suited to the needs of non-regular employees, as their protest could not be halted by the threat of dismissal. Such a direct and immediate expression of their interests also corresponded to their way of life, which as shown above was directed towards the satisfaction of immediate needs.

However, a definition limited to the location of industrial disputes and the form in which they are pursued is much too unspecific in the evidence it provides and must be narrowed down further. A more detailed distinction has to be drawn here among the ports examined. Direct actions aimed at gaining influence on working conditions (for example, gang numbers, weight of crane loads) developed in the US West Coast ports particularly after the strikes of 1934 and 1936-1937. These work stoppages are a characteristic everyday feature of Anglo-American labour movements generally and of the docks in these countries. ${ }^{123}$ Only such interruptions of work pursued by direct action should be described as job actions.

Job actions, though, are not always an effective weapon. The ILWU discovered this in 1938, when it tried to use job actions in the New Orleans docks. The outcome was shattering: the workers taking part were summarily dismissed. ${ }^{124}$ As shown by the following example, this tactic is effective only where it is backed up by good labour-market conditions (best of all when the labour market is under union control). Thus, on a Saturday

${ }^{150}$ On Ryan, see Kimeldorf, Reds or Rackets?, pp. 121f. and 153-156.

121 See ibid., pp. 261 and $112 f$.

12 See Amesen, Waterfront Workers of New Orleans, p. 105.

${ }^{123}$ See Boll, Arbeirskampfc, pp. 58 and 305; Babcock, "Longshoremen", p. 36f.; Phillips and Whiteside, Casual Labour, p. 278; Kimeldorf, "Social Origins", p. 339.

${ }^{124}$ See Bruce Nelson, "Class and Race in the Crescent City: The ILWU, from San Francisco to New Orleans", in Steve Rosswurm (ed.), The ClO's Lefi-Led Unions (New Brunswick, 1992), pp. 19-45 and 30. 
afternoon of the busy year 1919, longshoremen in New Orleans stopped working ${ }^{125}$ even though four small trucks full of sacks of flour were still waiting on the quay; they had left these over for the better-paid Sunday shift. They also exploited the favourable labour-market situation during the First World War to reduce their workload. For instance, in late 1917 they reduced from eight to seven the number of 140-pound sacks of flour to be moved by hand-truck. They also demanded that more men should be assigned to each job.

It was only in particular conditions that job actions took on a political thrust going beyond the workplace and the labour market. This was the case on the US West Coast between 1934 and 1938: here the strength of the dockworkers in the workplace and the labour market had given them a confidence which led them to extend their actions to political matters, such as anti-fascist protests. Their shared struggle against ruthless police methods in the recent labour disputes had also contributed to this politicization. ${ }^{126}$ However, these politicized job actions, like the syndicalist tendencies, are not a fact of nature, as Bruce Nelson appears to imply; ${ }^{127}$ they arise in consequence of behaviour patterns developed in the network of the labour market, the workplace and the harbour areas.

The strong collective confidence of the longshoremen was also evident in San Francisco during the Second World War, when the ILWU tried in vain to introduce piece-work. Rather than rashly politicizing every job action, it should be argued that these dockworkers saw their workplace as a territory which they alone wanted to control - employers, trade unions and political parties had to accept a subordinate role. For the West Coast dockworkers during the Second World War, this meant that "The longshoremen worked longer hours, put up with annoying military regulations, and even speeded up when they were convinced that doing so would aid the war effort, but they alone decided how, when and to what degree such sacrifices were to be made. [...] In this way, the wartime ethic code of personal sacrifice was held in check by the strong tradition of job control on the docks [...]"128

From the start of the twentieth century, direct actions aimed at gaining influence on working conditions - that is, job actions - were no longer common in Hamburg or in the German-speaking area in general. The same

125 On the following, see Amesen, Waterfont Workers of New Orleans, p. 225f.; Rosenberg, New Orleans Dockworkers, p. 167.

126 On this politicization, see Nelson, Workers on the Waterfront, pp. 168-174; Kimeldorf, Reds or Rackets?, p. 119; and on the effect of police actions, see Nelson, Workers on the Waterfront, pp. 168 and 185; Kimeldorf, "Sources of Working-Class Insurgency", p. 42.

127 See Nelson, "'Pentecost" ", p. 173.

128 Kimeldorf, "World War II and the Deradicalization of American Labor", p. 260f. There was a similar situation in New Orleans; see Amesen, Waterfront Workers of New Orleans, p. 172. In San Francisco job actions were also used to counter the Communist Party's efforts to increase the weight of the loads from 2,200 to 3,000 pounds during the productivity campaigns of the Second World War, see Kimeldorf, Reds or Rackets?, p. 136. 
was true of the control of the labour market. ${ }^{129}$ In pre-1914 Germany the high mobility of joumeymen in particular had led the early trade unions to concentrate their union activity outside the workplace. As for dock work in particular, from the start of the twentieth century the well-organized and highly centralized employers in Hamburg managed to suppress every attempt by workers and trade unions to intervene in the sphere of internal company power, where they claimed absolute authority. As a result, after the lost lock-out of 1907 the social-democratic dockworkers' trade union in Hamburg had withdrawn from all disputes on basic issues of work organization and the labour market and instead had concentrated on wages and working hours. As shown above, this tradition was interrupted only briefly in the exceptional years of 1919-1920, when power relationships in the workplace and on the labour market were called into question mainly by the syndicalist-oriented irregular dockers.

\section{CONCLUSION}

As shown in the above discussion, socio-historical studies should not treat dockworkers as a unified occupational group. Instead, there was an important dividing line between the regularly employed on the one hand and the irregularly employed and casual labourers on the other, even if it is not always possible to distinguish precisely between the last two groups in particular. The casual labourers' behaviour regarding disputes and organization was long presented as typical of all dockworkers. However, as has been shown here, this no longer coincided with the employment structures in dock work after roughly the beginning of the twentieth century. From this time on, the era of casual labour was drawing to an end in all the ports examined here, despite national differences, and was finally laid to rest by the developments of the mid-1930s and the Second World War. Workers regularly employed by individual companies now played an increasingly important role. By contrast, casual labour survived in British ports well into the 1960 s.

While working conditions in the ports considered here remained relatively unchanged until the 1960 s, particularly in the general cargo, two tendencies were evident in the development of labour-market organization in the first half of the century. The world economic crisis and the potential for social conflict represented by the large numbers of unemployed dockworkers were important factors. First, decentralized hiring of labour by foremen or middlemen became less and less common, and centralized

129 See Christiane Eisenberg, Deutsche und englische Gewerkschaften. Entsiehung und Entwicklung bis 1878 im Vergleich (Göttingen, 1986), pp. 12, 77f. and 258f.; Boll, Arbcitskämpfe, p. 252; Rudolf Boch, Handwerker-Sozialisten gegen Fabrikgesellschaft. Lokale Fachvereine, Massengewerkschaft und industrielle Rationalisierung in Solingen 1870 bis 1914 (Göttingen, 1985), pp. 15 and 293; and Gruttner, "Rank-and-File", p. $127 f$. 
labour markets were created. ${ }^{130}$ Second, more regular employment contracts were gradually introduced. As a result, the remaining irregular dockworkers were tied more closely to dock work as their only source of income, so that the casual labour mentality gradually vanished and was replaced by a stronger orientation towards regular work. In contrast to British ports, neither Hamburg nor San Francisco saw any fundamental resistance to the creation of a large centralized labour market and the superseding of casual labour. ${ }^{131}$ As may additionally be noted, the existence of a well-organized employers' side with dominant large companies was an important driving force behind the reduction of casual labour and the centralization of the dock labour market. But the move away from casual labour with its more self-determined way of living and working should not be seen as a loss: regular employment not only ensured higher and more reliable incomes for the remaining dockworkers but also improved their safety at work. After all, the previous long working hours and in particular the high proportion of casual labour had been responsible for the high accident risk in dock work. ${ }^{132}$

The town area around the docks, which at least in Hamburg was an impressive left-wing milieu, was criss-crossed by a close-knit communication network, with bars, public streets and squares and the labour exchanges as its central points. Assisted by its proximity to the workplace, this conjunction made it possible for the dockworkers, scattered across the ships, quays and piers during working hours, to meet and exchange experiences, thus strengthening their ability to act collectively. Nevertheless these districts did not create solidarity automatically. For instance, the harbour districts in New York were subdivided along ethnic lines. In the early 1930s in Hamburg, the split in the labour movement was also evident in these districts, when communist- and social-democratic-oriented dockworkers met in different bars there. It may be seen as a further important finding of the comparative approach that such marked ethnic differences did not exist among the Hamburg dockworkers.

The distinction made initially between regularly and irregularly employed workers is also of decisive importance for dockworkers' organization and conflict behaviour. The syndicalist organizations immediately after the First World War, like the communist trade unions in the 1930s, recruited their membership primarily from mobile irregular dockworkers. The types of dispute examined here, the direct actions and job actions,

130 The joint dock company structure created in Hamburg in 1934 was retained after the Second World War and was further extended in 1948 to include guaranteed minimum eamings for all dockworkers; see Weinhauer, "Arbeitsmarktorganisation", p. 293.

13! On these conflicts in British ports, see Phillips and Whiteside, Casual Labour, passim. 132 See Swanstrom, Waterfront Labour Problem, p. 86; Weinhauer, "Unfallentwicklung", p. 113; on the high accident rate in one Australian port, see Malcolm Tull, "Blood on the Cargo: Cargo-Handling and Working Conditions on the Waterfont at Fremantle, 19001939", Labour History (Australia), 52 (1987), pp. 15-29 and 23-26. 
were also tailored to the industrial needs of workers who were not bound to a particular company. Since they had no regular job to lose and could not be punished by a permanent dismissal, they were in a position to achieve immediate successes directly on the job and on the labour market by these means whenever the labour-market conditions were favourable.

However, nationally differing forms of dispute were concealed under the umbrella term of direct actions, which are to be seen as forms of industrial action without primarily political aims. In US ports these were the job actions that aimed at gaining influence on working conditions. As could be shown both for Hamburg (from summer 1919 until around the spring of 1921) and for San Francisco (1934-1938) it was only under special conditions that these took on a political thrust going beyond work and labour-market concerns. The decisive factor was a highly developed feeling of collective strength, which in both cases had become politicized through successful major labour struggles with the accompanying shared experiences of state repression. Considering the traditions of the German labour movement with its exclusion of workplace-related demands, it is obvious that the years 1919-1920 formed an exception on two counts. First, this period marks a hitherto unknown flourishing of syndicalist organizations. Second, during these years it was the irregularly employed dockers in particular who formulated a far-reaching claim to power in the workplace. Both factors were based on extraordinary experiences of power in the network of workplace, labour market and harbour districts.

Finally, the question should be raised whether the contrast between qualified and unqualified or skilled and unskilled workers should not similarly be abandoned in the analysis of the trade union organization and the dispute behaviour of other trades. For the dockworkers analysed here, at least, it has proved more productive, locally and from an international perspective, to analyse working conditions and labour-market conditions more precisely using the questions listed at the outset. Consideration of the rotational hiring introduced in the US West Coast ports in 1934 under trade union control has led to a differentiation of this set of questions: the mobility of the irregular dockworkers, with its potential for increased conflict, could be reduced not only through links to particular companies, but also through commitment to a union-promoted work ethos that every job should be carried out properly to union standards.

Overall, then, it should also have become clear how important it is for labour history to investigate the organization of the labour market and to analyse what norms and values became predominant in it and how these affected the work ethos of the relevant workers. A consideration of working conditions alone would have presented a misleadingly static picture in the case of the dockworkers. It remains to be examined in further studies whether and to what extent the interaction of labour market, workplace, work mentality and housing district discussed here with reference to the syndicalist organizations will lead to further advances in understand- 
ing for other aspects of dockworkers' militancy (for other organizations and industrial disputes). However, even a broad-based socio-historical analysis of this kind can only delimit the structural conditions for the conduct of disputes and the organizational behaviour of various groups of dockworkers. More precise conclusions will become possible only when the modes of behaviour of the people in this network are reconstructed in concrete historical situations. 